\title{
Reflections of Mathematics Student Teachers' Knowledge Related to the Purposes of the Curriculum on Their Limit Teaching*
}

\author{
Semiha KULA ${ }^{* *}$
}

\author{
Esra BUKOVA GÜZEL ${ }^{* * *}$
}

Received: 11 April 2013

Accepted: 30 December 2014

\begin{abstract}
The aim of the study is to examine reflections of the mathematics student teachers' knowledge related to the purposes of the national mathematics curriculum on their limit teaching. The participants were four mathematics student teachers in the final year of their program. The data were obtained from participants' lessons plans, video recordings of their lessons in which they taught the concept of limit, and semi-structured interviews. The reflections of the mathematics student teachers' knowledge related to the purposes of the mathematics curriculum on their limit teaching was composed of under the titles of relating real life with limit concept, relating with different areas, providing mathematical thinking and reasoning, improving ability to communicate, using mathematical language, relating mathematics with art, and using technology effectively.
\end{abstract}

Keywords: pedagogical content knowledge, curriculum knowledge, the purposes of national mathematics curriculum, limit, mathematics student teachers.

\section{Extended Abstract}

Purpose and Significance: It is stated that teaching of limit concept which is difficult to be understood need to be well planned (Elia, Gagatsis, Panaoura, Zachariades, \& Zoulinaki, 2009). In our country, the national high school mathematics curriculum is one of the main resources. Teachers plan and conduct their lessons by taking into account of the purposes of the related concept and the mathematics curriculum. Because of this, it is considered that while planning the lessons it is important for teachers and student teachers to realize the purposes in question. In this direction, the aim of the study is to examine reflections of the mathematics student teachers' knowledge related to the purposes of the national mathematics curriculum on their limit teaching.

Methods: In this study, the case study which is one of the qualitative research designs was used to examine reflections of the mathematics student teachers' knowledge related to the purposes of the national mathematics curriculum on their limit teaching in a detail way on the actual classroom environment. The participants were four senior secondary mathematics student teachers (three females and one male) who are studying at the department of secondary school mathematics education. In Turkey, the secondary

\footnotetext{
* This study is constituted from a part of Semiha KULA's master thesis supervised by Assosiate Professor Dr. Esra BUKOVA GÜZEL. The thesis study named "Examining Mathematics Pre-service Teachers' Subject Matter and Pedagogical Content Knowledge by Using Knowledge Quartet: The Case of Limit" also supported by the Scientific Research Projects of Dokuz Eylül University (No. 2009.KB.EGT.001).

${ }^{* * *}$ Asst. Prof. Dr., Dokuz Eylul University, İzmir, Turkey, semiha.kula@ deu.edu.tr

**** Corresponding Author: Assoc. Prof. Dr., Dokuz Eylul University, İzmir, Turkey, esra.bukova@ deu.edu.tr
} 
mathematics student teachers are educated in five year thesis without master programs. The first three-and-half years are considered an undergraduate program and the last oneand-half years are considered as a non-thesis masters' program. The data was obtained from the participants' four hour lessons plans towards the limit concept, video recordings of these lessons, and the voice records of semi-structured interviews. While analyzing the video records of the participants' lessons, both descriptive summaries were prepared and in the later process, the video records were transcribed verbatim. The descriptive summaries in question were prepared to determine the interviews' questions which would be asked to the participants after their lessons. The so-called transcripts included the expressions of the student teachers and the students, the screenshots of the presentations and videos projected on the screen by the student teachers and the things that the student teachers and the students wrote on the board. The voice records of the interviews were also transcribed verbatim. These transcriptions were used to support the findings obtained from the lesson plans and lessons of the student teachers related to their purposes of the national mathematics curriculum. The reflections of the mathematics student teachers' knowledge related to the purposes of the national mathematics curriculum on their limit teaching was handled with categories named relating real life with limit concept, relating with different areas, providing mathematical thinking and reasoning, improving ability to communicate, using mathematical language, relating mathematics with art, and using technology effectively.

Results: The reflections of the mathematics student teachers' knowledge related to the purposes of the mathematics curriculum on their limit teaching was composed of under the titles of relating real life with limit concept, relating with different areas, providing mathematical thinking and reasoning, improving ability to communicate, using mathematical language, relating mathematics with art, and using technology effectively. It was seen that the participants were aware of the purposes of the limit concept and the mathematics curriculum. Additionally, they planned and conducted their lesson by means of these purposes. While one of the participants did not prefer to use the real life examples in his lessons, the other three participants mainly used the real life examples in their first lessons in which the idea of the limit concept was begun to construct. The participants preferred to relate the limit concept with the geometric concepts. One of the participants also tried to use the examples related to the limit concept with the physical concepts. Generally, the participants tried to use the mathematical terminology and mathematical languages in a correct way. They also paid attention to their students' usage of mathematical languages. Two of the participants took advantage of the art, especially Eschers' paintings, in their limit teaching. On the other hand one participant used a video constructed by combining the geometrical shapes in an esthetics way in the beginning of her first lesson. In this way, she attracted her students' interests to the lesson and the limit concept. Three of the participants conducted their lessons with the PowerPoint presentations prepared by them. Also two participants integrated the mathematical software to their lessons. 
Discussion and Conclusions: the participants' viewpoints related to mathematics teaching took an active role while determining their teaching approaches used in lessons. The student teachers who adopted the constructivist learning approach were tried to mention why the limit concept was learned, when the limit concept would be used, and how the limit concept was related to the real life and the other disciplines. On the other hand, the participant who adopted the traditional approach thought that mathematical concepts would be learned by traditional approach. He also stated that learning would only be occurred if the students desired to it. From this point of view, the cases of giving places to the mathematics teaching purposes in student teachers' lessons were affected by their adopted approaches about teaching and learning. 


\section{Matematik Öğretmeni Adaylarının Öğretim Programının Amaçlarına Yönelik Bilgilerinin Limit Öğretimlerine Yansımaları*}

Semiha KULA ${ }^{* *}$

\author{
Esra BUKOVA GÜZEL ${ }^{* * *}$
}

Makale Gönderme Tarihi: 11 Nisan 2013

Makale Kabul Tarihi: 30 Aralık 2014

ÖZET: Bu çalışmanın amacı; matematik öğretmeni adaylarının Ortaöğretim Matematik Dersi Öğretim Programının amaçlarına yönelik bilgilerinin gerçek sınıf ortamlarındaki limit öğretimlerine yansımalarını incelemektir. Araştırma ortaöğretim matematik öğretmenliği son sınıfında öğrenim görmekte olan dört öğretmen adayı ile gerçekleştirilmiştir. Veriler; katılımcıların limit kavramına yönelik hazırladıkları ders planlarından, bu derslerin video kayıtlarından ve yarı-yapılandırılmış görüşmelerin ses kayıtlarından derlenmiştir. Katılımııların öğretim programının amaçlarına yönelik bilgilerinin limit öğretimlerine yansımaları; günlük yaşamla ilişkilendirme, farklı öğrenme alanlarıyla ilişkilendirme, matematiksel düşünme ve akıl yürütmeyi sağlama, iletişim kurma becerisini geliştirme, matematik dilini kullanma, matematik ile sanatı ilişkilendirme ve teknolojiyi etkin kullanma başlıkları altında şekillenmiştir.

Anahtar sözcükler: alan öğretimi bilgisi, program bilgisi, matematik programının amaçları, limit, matematik öğretmeni adayı.

\section{Giriş}

Öğretmenlerin sahip olması gereken bilgi türlerinin neler olduğu ilk kez Shulman'ın çalışmaları ile ortaya koyulmuştur. Shulman (1987) öğretmenlerin sahip olmas1 gereken yedi bilgi türünü, genel öğretim bilgisi; öğrenen bilgisi; eğitim ortamı bilgisi; eğitimsel amaçlar, değerler ve bunların tarihi ve felsefi kökenleri bilgisi; alan bilgisi (AB); alan öğretimi bilgisi (AÖB) ve öğretim programı bilgisi olarak adlandırmaktadır. Bu bilgi türlerinden ilk dördü alana bakılmaksızın öğretmenlerin sahip olması gereken genel bilgi türleri olarak karşımıza çıkarken, son üç bilgi ise; alana özgü bilgiler olarak görülmektedir (Rowland, Turner, Thwaites, \& Huckstep, 2009). Shulman'a (1986) göre AB bir öğretmenin ne bildiği, ne kadar bildiği ve ne bilmesi gerektiği ile ilgili (Ball, \& McDiarmid, 1990; Leavit, 2008) iken AÖB bir öğretmenin AB'sini öğrencilerinin konuyu anlayabilmelerine olanak sağlayacak formlara dönüştürme kapasitesine dayanmaktadır (Shulman,1987). Shulman (1986) program bilgisini ise; belli bir düzeydeki bir konunun veya özel bir alanın öğretimi için tasarlanan programların tüm bileşenlerinin farkında olma, bu programlara ilişkin var olan öğretimsel araçların çeşitliliğinin farkında olma ve özel bir durumda özel bir program aracının kullanımı için hem uygun olan hem uygun olmayan özelliklerin farkında olma olarak tanımlamaktadır.

Grossman (1990) AÖB'ü; öğretmenlerin konuları öğretme amaçları hakkındaki bilgi ve inançları, öğrencilerin ön öğrenmeleri ve kavram yanılgıları hakkındaki

\footnotetext{
* Bu çalışma birinci yazarın ikinci yazar danışmanlığında yürütülen ve Dokuz Eylül Üniversitesi Bilimsel Araştırma Projeleri birimi tarafindan desteklenen (No. 2009.KB.EGT.001) "Matematik Öğretmen Adaylarının Dörtlü Bilgi Modeli ile Alan ve Alan Öğretimi Bilgilerinin İncelenmesi Limit Örneği” isimli yüksek lisans tezinin bir bölümünden oluşturulmuştur. Çalışma 20. Ulusal Eğitim Bilimleri Kongresi'nde sunulan bildirinin genişletilmiş halidir.

***Yrd. Doç. Dr., Dokuz Eylül Üniversitesi, İzmir, semiha.kula@deu.edu.tr

*** Sorumlu Yazar: Doç. Dr., Dokuz Eylül Üniversitesi, İzmir, esra.bukova@ deu.edu.tr
} 
bilgileri, farklı konular arasındaki ve konu içerisindeki ilişkileri içerecek seviyede müfredat bilgisi ve öğretim stratejileri hakkında bilgileri olmak üzere dört öğe ile tanımlamaktadır. Marks (1990) ise AÖB'ün öğretim amaçlarının belirlediği konu alanı bilgisi, öğrencilerin konu alanındaki anlayışlarına dair bilgisi, konu alanının öğretiminde kullanılacak araçlar bilgisi ve öğretme süreçlerine dair bilgi olmak üzere dört ana bileşenden oluştuğunu ifade etmektedir. Benzer şekilde Schoenfeld (1998) AÖB’ü öğretmenin bir konunun öğretimi için gerekli amaçlar bilgisi, öğrencilerin anlayışları ve o konunun alanına yönelik olası yanlış anlayışları bilgisi, program ve programa ilişkin araçlar bilgisi, belli bir konunun öğretimi için gösterimler ve stratejiler bilgisi olarak dört ana bileşenden yararlanarak ortaya koymaktadır. Buradan, alana özgü bilgiler ile ilgili yapılan tanımlamalarda bazen benzer bazen farklı bileşenlere dikkat edildiği görülmektedir. Örneğin; Shulman (1987) program bilgisini ayrı bir bilgi kategorisi olarak ele alırken, daha sonraki çalışmaların hemen hemen tümünde program bilgisi AÖB'ün bir bileşeni olarak ele alınmaya başlanmıştır (An, Kulm, \& Wu, 2004; Chick, Baker, Pham, \& Cheng, 2006; Grossman, 1990; Hill, Ball, \& Schilling, 2008; Leavit, 2008; Magnusson, Krajcik, \& Borko, 1999; Marks, 1990; Schoenfeld, 1998; Tamir, 1988). Bu doğrultuda, matematik öğretmenlerinin ve matematik öğretmeni adaylarının sahip olması gereken alana özgü bilgi türleri; matematik alan bilgisi, matematik öğretimi bilgisi ve matematik dersi öğretim programı bilgisi olarak ifade edilebilmektedir.

Bukova Güzel (2010) farklı araştırmacıların AÖB'e ilişkin çerçevelerinden yararlanarak oluşturduğu ve matematik öğretmeni adaylarının AÖB'lerini değerlendirmede kullandığı çerçevede, program bilgisinin alt bileşenlerini; matematik programının amaçlarının farkında olma/kullanma, matematik programındaki öğretimsel araçların çeşitliliğinin farkında olma/kullanma, öğrenmeleri ölçmede kullanılabilecek araçların farkında olma/kullanma ve bir konu için yatay ve dikey program bilgisine sahip olma/kullanma olarak ifade etmektedir.

Çalışma kapsamında program bilgisine ait "matematik dersi öğretim programının amaçlarının farkında olma/kullanma" alt bileşenine ve limit öğretimi sürecine bu bilginin nasıl yansıdığına odaklanılmaktadır. "Süreklilik", "türev" ve "integral” kavramlarının, doğrudan doğruya bağlı olduğu "limit” kavramının (Sanchez, 1996) önemi şu şekilde ifade edilmektedir:

Fonksiyon kavramının uygulamada ve üst kavramların oluşturulmasında kullanılabilmesi için ona ilişkin "limit”, "türev”, "süreklilik" ve "integral” kavramlarının da öğrenilmesi gerekir. Öte yandan, "süreklilik", "türev" ve "integral" kavramlarının, doğrudan doğruya "limit" kavramına bağlı olduğu da bilinmektedir (Sanchez, 1996). Bir başka deyimle, bireyin "limit" kavramını öğrenme sürecindeki her türlü sıkıntı giderilmeden, "süreklilik", "türev" ve "integral" kavramlarını oluşturması ve öğrenmesi düşünülemez. Bunun devamında da fonksiyonun uygulamada kullanımı zorlaşır. Benzer biçimde "sayı" kavramının genişletilmesi de limit ile doğrudan bağlantılıdır ve limit kavramında oluşmuş her tür eksiklik sayı kavramının genişletilmesini de engeller. Daha açıkçası, toplama, çıkarma, çarpma ve bölme işlemlerinin "Temel Matematik" çalışmalarında üstlendiği görevi, daha üst düzey matematikte "limit" üstlenir denebilir. O nedenle, matematikçiler "limit" kavramını matematiğin "beşinci işlem" i olarak adlandırırlar (Bukova, 2006, s.5). 
Limit kavramının bunca önemine karşılık yapılan araştırmalar limit kavramında hem matematik öğretmenlerinin, hem matematik öğretmeni adaylarının hem de öğrencilerin sıkıntı yaşadıklarını ortaya çıkarmaktadır (Bukova, 2006; Hofe, 1997; Orton, 1983; Sanchez, 1996). Anlaşılması zor bir kavram olan limitin öğrenme ve öğretme sürecinin iyi planlanmasının gerektiği (Elia, Gagatsis, Panaoura, Zachariades, \& Zoulinaki, 2009) ifade edilmektedir. Ülkemizde öğretimin planlanmasında Ortaöğretim Matematik Dersi Öğretim Programı (OMDÖP) temel kaynaklardan biridir. OMDÖP'de kavramsal bilgiye odaklanılmakta ve matematik öğretimi ile öğrencilerin geleceğe hazırlanmalarını; matematiksel beceri ve yeteneklerini geliştirmelerini; teknolojik değişimleri takip etmelerine imkan verecek zihinsel becerileri kazanmalarını ve matematiğin sistematik bir bilgi ve bilgisayar dili olduğunu öğrenmelerini sağlamak hedeflenmektedir (MEB, 2006). OMDÖP'ün amaçları genel olarak;

- matematiksel bilgileri, kavramları ve becerileri kazanma,

- kavramlar arasında ilişki kurma,

- matematiği günlük yaşam ve diğer bilim dallarıyla ilişkilendirme,

- matematiksel düşünme, akıl yürütme, ilişkilendirme, genelleme, iletişim kurma, problem çözme, modelleme ve tahmin etme becerisi kazanma,

- matematiksel terminoloji ve dili doğru kullanma,

- matematiğe yönelik olumlu tutum geliştirme,

- matematiğin tarihsel gelişimini ve önemini kavrama,

- matematik ve sanat arasında ilişki kurma ve estetik duyguları geliştirme

şeklinde ifade edilmektedir (MEB, 2006).

Öğretmenler konunun kazanımlarını, öğretim programının amaçlarını ve gerektirdiklerini göz önüne alarak matematik derslerini planlamaktadırlar. Matematik öğretmenlerinin ve eğitim süreci devam eden matematik öğretmeni adaylarının derslerini planlamaları için söz konusu amaçların farkında olmalarının önemli olduğu düşünülmektedir. $\mathrm{Bu}$ doğrultuda çalışmanın amacı; matematik öğretmeni adaylarının OMDÖP'ün amaçlarına yönelik bilgilerinin gerçek sınıf ortamlarındaki limit öğretimlerine yansımalarını incelemektir.

\section{Yöntem}

Araştırmada matematik öğretmeni adaylarının OMDÖP'ün amaçlarına yönelik bilgilerinin gerçek sınıf ortamlarındaki limit öğretimlerine yansımaları ayrıntılı olarak incelenmek istendiğinden nitel araştırma yöntemlerinden biri olan özel durum çalışmasından yararlanılmıştır. Bu çalışma; öğretmen adaylarının Okul Deneyimi II dersi kapsamında gözlem ve uygulama yaptıkları uygulama okulundaki 12. sınıflarında limit kavramının işlendiği süreçte gerçekleştirilmiştir. Öğretmen adaylarının limit öğretimine yönelik dersleri matematik öğretiminin amaçlarına uygunluk açısından ayrıntılı olarak incelenmiştir. 


\section{Katılımcilar}

Araştırma ortaöğretim matematik öğretmenliğinde öğrenim gören dört son sınıf matematik öğretmeni adayı ile gerçekleştirilmiştir. Çalışma öncesinde katılımcılara çalışma hakkında bilgi verilmiş ve gönüllü olan öğretmen adayları katılımcı olarak seçilmiştir. Katılımcıların gerçek isimleri gizli tutulmuş, bulgular sunulurken kendilerinin belirlemiş oldukları takma isimler (Deniz, Umay, Can, Alev) kullanılmıştır. Katılımcılar bir Anadolu Lisesi'nin 12. sınıfında limit kavramına ilişkin öğretimlerini gerçekleştirmişlerdir. Dörder saati kapsayan öğretimleri boyunca bir gerçek sayıya yaklaşım, bir noktadaki soldan ve sağdan limit, limit özellikleri ve uygulamaları, parçalı tanımlı fonksiyonların limitleri, genişletilmiş gerçek sayılar kümesinde limit, trigonometrik fonksiyonların limiti ve limitte belirsizlik durumlarına değinmişlerdir. Katılımcıların öğretimlerini yürüttükleri sınıflarında 13-15 öğrenci bulunmuştur.

Katılımcılardan çalışmanın başında ilk olarak kendilerini tanıtıcı makaleler yazmaları ikinci olarak da matematik ve matematik öğretimine yönelik inanışlarının anlaşılması için yapılandırılmış bilgi formunu doldurmaları istenmiştir. Katılımcıların makaleleri ve tanıtıcı bilgi formları doğrultusunda genel anlayışları ortaya çıkarılmaya çalışılmıştır. Dört öğretmen adayı özel ders vermeleri nedeniyle öğretmenlik deneyimi yaşadıklarını ifade ederken, ek olarak Can özel bir dershanede iki yıllık öğretmenlik deneyimi yaşadığını, Alev ise yardım amaçlı bir kurumda bir sınıfa yıl boyunca gönüllü olarak ders anlattığını ifade etmiştir.

Deniz matematiği bir ders olması dışında uğraşmaktan zevk aldığı bir uğraşı ve yaşamda olup bitenlerin nedenini açıklamaya yarayan bir bilim olarak tanımlamıştır. Öğrencilerinin matematiği bu yönü ile görmelerini hedefleyerek, matematiği yaşamla ilişkilendirmeye, kavramsal öğrenmeye ve birlikte çalışmaya önem vermiştir. Bunun yanında Deniz, öğrencilerin düşüncelerine ve birbirlerinin düşüncelerini dinleyip eleştirmelerine önem verilmesi gerektiğini belirtmiştir. Kendi öğrencilik yıllarındaki öğretmenlerin düz anlatım ile öğretimlerini gerçekleştirdiklerinden ve matematiği niçin öğrettiklerine, ne yararı olacağına ve nerede kullanılacağına değinmediklerinden bahseden Deniz, derslerde genel olarak bilgilerin doğrudan aktarılmamasını, öğrencilere keşfettirilmesini dile getirerek kendini yapılandırmacı anlayışı benimseyen bir öğretmen olarak tanımlamıştır.

Umay matematik öğretiminde kavramların günlük hayatla ilişkilendirilmesinin önemli olduğuna inandığını ifade etmiştir. Öğrencilik yıllarında matematik öğretmenlerinin genelde tanımları ve soruları tahtaya yazarak ve onlardan da yazılanları defterlerine geçirmelerini isteyerek dersleri işlediklerini belirtmiş ve kendisinin bu tarz bir öğretmen olmak istemediğini dile getirmiştir. Öğretimde, konuların neden öğrenildiğine değinilmesine, teknoloji ve teknolojinin sunduğu imkanlardan yararlanılmasına, tartışma ortamı oluşturulmasına ve öğrencilerin odakta tutulmasına önem verdiğini belirtmiştir. Öğrencilerin kavramları ve özelikleri örnekler ile uğraşarak kendilerinin keşfetmelerinin gerekliğine vurgu yapmıştır.

Alev matematik öğretiminde ispatlara ve kavramların anlaşılmasına soru çözebilmeden daha çok önem verdiğini, bu bağlamda yaşamla ilişkilendirme yapmaya 
ve mümkün oldukça doğrudan ezbere bilgi vermemeye çalıştığını belirtmiştir. Alev teknolojinin sunduğu imkanlardan yararlanmak gerektiğine değinmiş ayrıca yapılandırmacı yaklaşımı savunduğunu belirtmiştir. Ancak Alev'in alan bilgisindeki eksiklikler zaman zaman öğrenci sorularına yanıt vermede ve öğretimi bunlara göre şekillendirmede sıkıntılar yaşamasına neden olmuştur.

Can nasıl anlatılırsa anlatılsın öğrenmenin tamamıyla öğrenecek olan kişinin isteğine bağlı olduğunu dile getirerek geleneksel öğretim ile de kişinin öğrenebileceğine inandığını belirtmiştir. Kendisinin de geleneksel yaklaşımla öğrendiğini ve sıkıntı yaşamadığını ifade ederek, öğrenmek istemeyen bir kişiye nasıl bir öğretim yapılırsa yapılsın etkili olunamayacağını belirtmiştir. Matematiksel kavramların kendi arasında ilişkilerin kurulmasının bir ölçüde etkili olabileceğini ama yaşam ile ilişkilendirmenin çok da gerekli olmadığını vurgulamıştır. Derslerini daha çok sorular ve sorulara çözüm arama ile şekillendirmenin uygun olduğuna inanmıştır. Öğretimde etkinliklerden yararlanmak yerine geleneksel olarak tanım verme, örnek soru çözümleri gerçekleştirme ve öğrencilerine sorular sorma üzerine odaklanmıştır. Grup çalışması yaptırmak yerine öğrencilerin bireysel olarak soru çözümleri yaparak tahtaya kaldırılmalarını önemsediğini dile getirmiştir.

\section{Veri Toplama Araçları}

Veriler; katılımcılar tarafından limit kavramına ilişkin hazırlanan dörder saatlik ders planlarından, söz konusu derslerin video kayıtlarından ve yarı yapılandırılmış görüşmelerin ses kayıtlarından derlenmiştir. Katılımcılar, OMDÖP'ü temel alarak ders planlarını hazırlamışlardır. Katılımcıların ders işleyişıleri araştırmacılar tarafından gözlemlenmiş ve daha sonra ayrıntılı olarak inceleyebilmek amacıyla tüm dersler video kamera ile kaydedilmiştir. 16 ders saatini içeren video çekimlerinden sonra katılımcıların tüm dersleri için tanımlayıcı özetler oluşturulmuştur. Katılımcılar ile yapılan yarı-yapılandırılmış görüşmeler bu tanımlayıcı özetler temel alınarak gerçekleştirilmiş ve tüm görüşmeler esnasında ses kayıt cihazı kullanılmıştır. Katılımcılar ile ders öncesi, ders sonu ve genel görüşmeler gerçekleştirilmiştir.

\section{Verilerin Analizi}

Katılımcıların dersleri izlendikten sonra bire-bir yazıya aktarım için uygun olduğu düşünülen format belirlenmiştir. $\mathrm{Bu}$ format katılımcıların ve öğrencilerin ifadelerini, projeksiyon ile yansitılan sunumlar ile tahtaya yazılanların ekran alıntısı arac1 ile alınmış görüntülerini içerecek şekilde oluşturulmuştur. Tüm derslerin video kayıtlarının bire-bir yazıya aktarımı sonucunda 547 sayfalık doküman elde edilmiştir. Söz konusu dokümanlar analiz edilirken, katılımcıların matematik öğretiminin amaçlarına yönelik bilgilerinin limit öğretimlerine yansımaları;

- günlük yaşamla ilişkilendirme,

- farklı öğrenme alanlarıyla ilişkilendirme,

- matematiksel düşünme ve akıl yürütmeyi sağlama,

- iletişim kurma becerisini geliştirme, 
- matematik dilini kullanma,

- matematik ile sanatı ilişkilendirme,

- teknolojiyi etkin kullanma başlıkları altında şekillenmiştir.

\section{Bulgular}

Matematik öğretmeni adaylarının OMDÖP'ün amaçlarına yönelik bilgilerinin limit öğretimlerine yansımalarının incelendiği çalışmada bulgular; günlük yaşamla ilişkilendirme, farklı öğrenme alanlarıyla ilişkilendirme, matematiksel düşünme ve akıl yürütmeyi sağlama, iletişim kurma becerisini geliştirme, matematik dilini kullanma, matematik ile sanatı ilişkilendirme ve teknolojiyi etkin kullanma başlıkları altında ele alınmaktadır.

\section{Günlük Yaşamla İlişkilendirme}

Katılımcılar günlük yaşamla ilişkilendirmeyi ağırlıklı olarak limit kavramının oluşturulmaya başlandığı ilk derslerinde kullanmayı tercih etmişlerdir. Bununla birlikte Umay ve Deniz genişletilmiş gerçek sayılar kümesinde limiti oluştururken sonsuzluk kavramını ele almışlar ve bu aşamada da günlük yaşam örneklerinden yararlanmışlardır. Can limit kavramını günlük yaşamla ilişkilendirmeye çalışmazken, Umay günlük yaşamla ilişkilendirmeyi en fazla yapan katılımcı olmuştur. Umay’ın limit kavramını günlük yaşamla ilişkilendirmeyi hemen hemen bütün derslerine yaydığı görülmüştür. Umay kendisi ile ders öncesi yapılan görüşmede limiti günlük yaşamla ilişkilendirme konusunda aşağıdaki ifadeleri kullanmıştır:

Daha sonra öğrencilerin daha kolay, bu konuyu daha kolay nasıl anlayabileceğini düşündüm ve günlük hayatla konuyu ilişkilendirmeye çalıştım. Günlük hayat örnekleri düşündüm. Buradan başladım... Bu günlük hayatla ilişkilerimi matematikle ilişkilendirerek konuya bir giriş yapmayı düşünüyorum. Böylece daha kalıcı bir anlatım olacağını düşünüyorum. (Umay-Ders Öncesi Görüşme)

Umay birinci dersinde limit kelimesinin Türkçe'de ne anlama geldiğini öğrencileri ile aşağıdaki gibi paylaşmış ve böylelikle günlük yaşamda limit kelimesinin kullanımı ile matematikteki limit kavramı arasında ilişki kurmayı amaçlamıştır.

Umay: Peki, Türkçe anlamına bakalım. Limitin Türkçesine. Limit bir şeyin nicelik bakımından inebileceği ya da erişebileceği en alt ve en üst sınır, yer. Değişken bir büyüklüğün istenildiği kadar yaklaşabildiği durağan büyüklük. Ya da hudut tayin etmek, kısıtlamak, sinırlandırmak gibi anlamları var.

Umay ve Alev birinci derslerinde günlük yaşamla limit kavramını ilişkilendirme ve limit kavramını sezdirme amacıyla hız limiti, kredi kartı limiti gibi günlük yaşamda kullandığımız limit kelimesine ilişkin örnekleri vermiştir. Alev’in birinci dersinde verdiği hız ve kredi kartı örneklerine ilişkin kesit aşağıda verilmiştir.

Slayt:

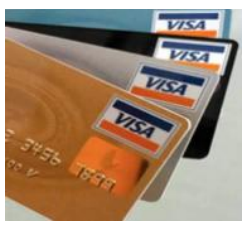




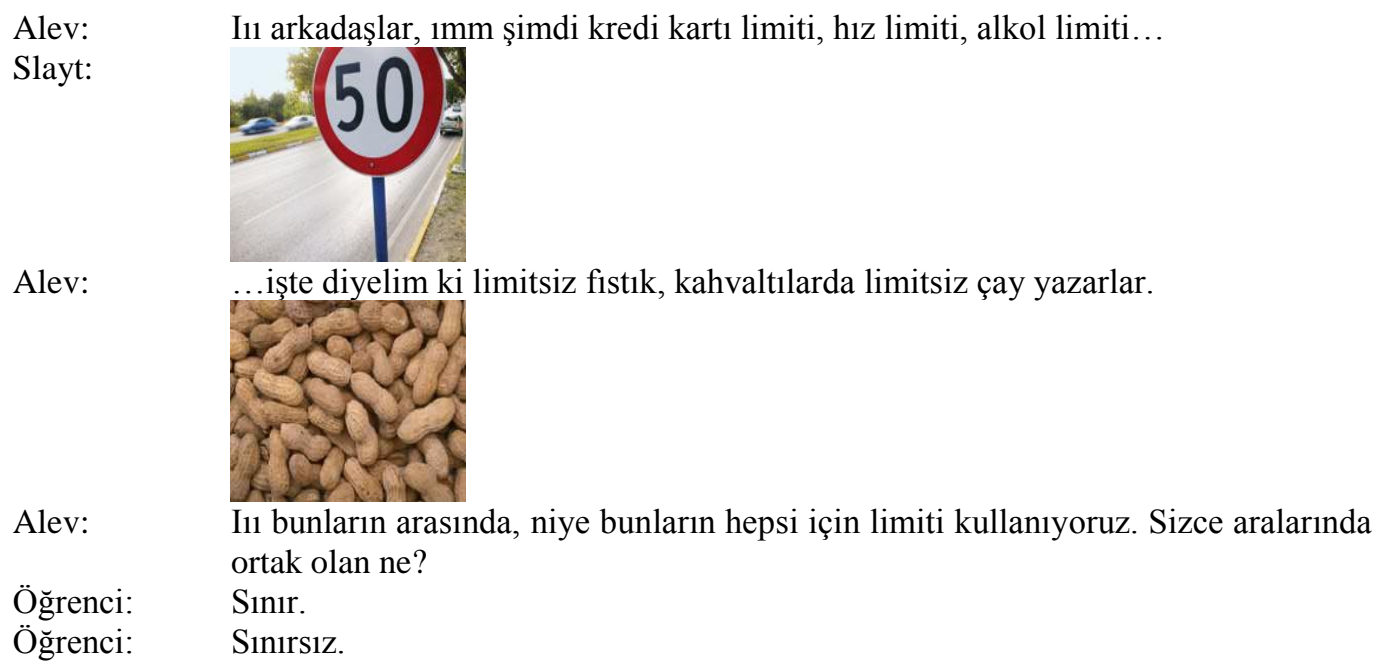

Umay uçurum ile ilgili izlemiş olduğu bir animasyonu limit kavramına girişte kullanmanın ilgi çekici olacağını düşünmüş ve birinci dersinde kullanmıştır. Söz konusu örnekte uçurum kenarına ne kadar yaklaşılabileceğine ve sınırın aşıldığında ne olacağına ilişkin bir örneklendirme yapılmıştır. Söz konusu animasyondan kesitler Şekil 1 'de verilmiştir.

Şekil 1. Umay'ın uçurum animasyonundan kesitler

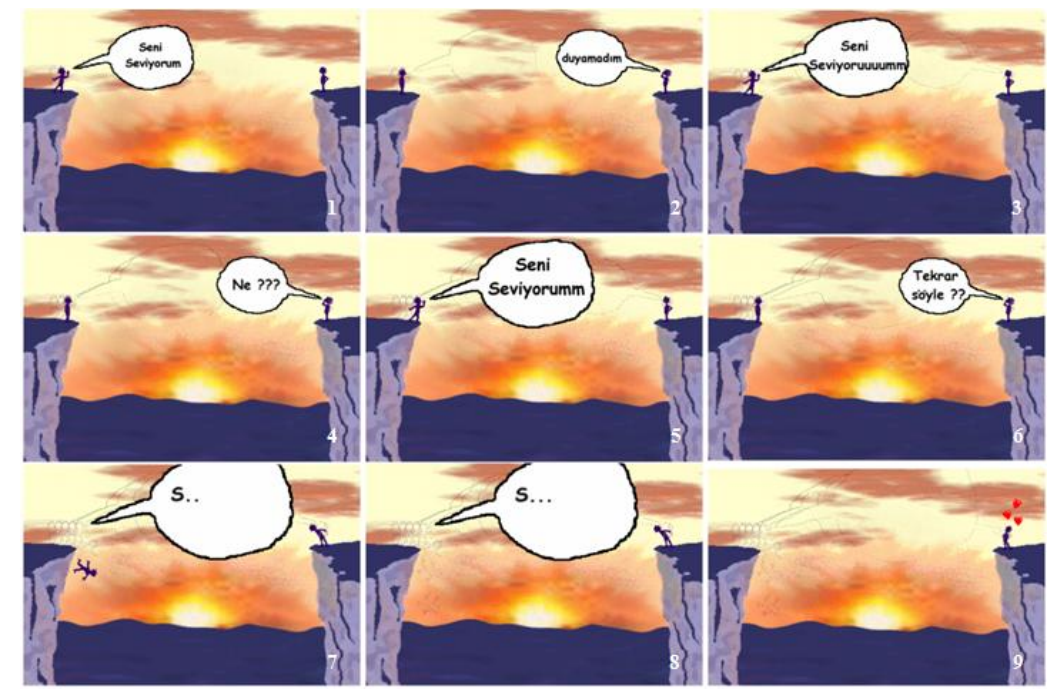

Umay resim konusundaki becerisini de kullanarak limit kavramını Ünlüye Yaklaşım Örneği ile ilişskilendirmiştir. Umay’ın birinci dersinde kullandığı söz konusu örneğe ilişkin kesitler aşağıda verilmiştir.

Umay: $\quad$ Peki, arkadaşlar biraz daha günlük hayata geçelim. Hepimiz az çok magazinle

Öğrenci: $\quad$ Haberci.

Umay: $\quad$ Evet, haberciler değil mi? Sağdan, soldan, her taraftan hemen üşüşürler. 
Slayt:

\section{Phition}

Umay: Peki, nerden ünlüye doğru yaklaşabilirler?

Öğrenci: $\quad$ Sağdan ve soldan.

Öğrenci: Her yerden.

Umay: Săgdan.

Slayt:

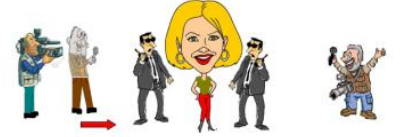

Umay: Soldan.

Umay: $\quad$ Biri kazma kürek alsa eline. Aşağıdan yaklaşsa.

Slayt:

Umay: $\quad$ Bir şekilde yaklaşırlar, değil mi? Peki bu yaklaşım işlerinin sonunda ünlüye ulaşabilirler mi? Yani mikrofonu ağzına değdirebilirler mi? Eliyle işte kolunu tutabilirler mi?

Can ise limit kavramına ilişkin derslerini günlük yaşamla hiç ilişkilendirmeden yürütmeyi tercih etmiştir. Can günlük yaşamla ilişkilendirme yapmayı tercih etmediğini derslerinden önce kendisiyle yapılan görüşmede aşağıdaki gibi ifade etmiştir:

Şimdi hep matematiğin içinde kalacağız, matematiğin dışına çıkmayacağız. (Can-Ders Öncesi Görüşme)

\section{Farklı Öğrenme Alanlarıyla İlişkilendirme}

Katılımcılar limit kavramını genellikle geometri ile ilişkilendirirken ek olarak Umay fizik dersi ile de ilişkilendirme yapmayı tercih etmiştir. Deniz limit kavramını geometri ile ilişkilendirecek örnekler vereceğini ancak farklı disiplinler ile ilişkilendirme yapmayacağını ders öncesi yapılan görüşmede aşağıdaki gibi belirtmiştir.

Dersler arası, açıkçası yapmadım. Ama düşünüyorum şu an var mı diye. Farkında olmadan yapmış olduğum bişey de yok sanırım yani. Tek disiplin arası, tek disiplinde, matematikte sadece ilişkilendirdim. (Deniz-Ders Öncesi Görüşme)

Alev limit kavramını, flash programında hazırlanmış bir animasyonu kullanarak geometri ile ilişkilendirmiştir. Söz konusu programda, köşeleri çemberin üzerinde olan düzgün çokgenlerin kenar sayısını girerek iç teğet çokgeni, dış teğet çokgeni ve dairenin alanı arasındaki ilişkileri sezdirmeyi amaçlamıştır. Böylece animasyondan yararlanarak üç alan arasında ilişki kurmuş ve kenar sayısı arttıkça üç alanın birbirine daha çok 
yaklaştı̆̆ını ifade etmiştir. Alev, derslerinde matematiği daha zor hale getirmemek için disiplinler arası ilişkilendirme yapmayı tercih etmediğini ders öncesi görüşmesinde aşağıdaki gibi açıklamıştır.

I1111, diğer alanlarla çok fazla, 1mm nasıl diyim, bağdaştırmak da istemedim doğru söylemek gerekirse çünkü diğer işte genelde matematikteki kavramları fizikle ya da kimyala ile işte o tarz derslerle bağdaştırabiliyoruz. Ve zaten matematik yeterince korkunçken diğer sayısallar işin içine girince biraz daha onlara itici geliyo diye düşünüyorum benim fikrim. (Alev-Ders Öncesi Görüşme)

Can, Alev'in flash programı etkinliği ile ulaştığ 1 sonuçlara tahtaya yaptığı kendi çizimleri ile ulaşmaya çalışmış devamında ise eğri altında kalan alanı hesaplamak için dörtgenlerden yararlanmaya geçmiştir. Böylece geometri ile limiti ilişkilendirmiş, ancak diğer bilim dalları ile ilişkilendirme yapmayı tercih etmemiştir.

Tahta:

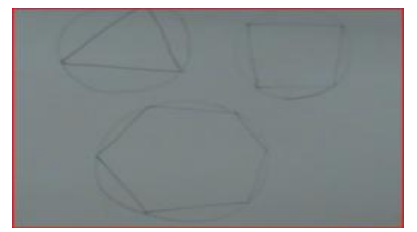

Can: $\quad$ Noldu? Şurda kalan alanlar gitgide daha az oldu, değil mi? Peki, ben sonsuz kenarlı bir çokgen çizsem bu çemberin içersine o zaman ne olur? Şurda kalan alanlar sıfır olur değil mi? Çok küçük, çok çok küçük bi alan kalır dişarıda. Ve ben bu sonsuz kenarlı çokgenin alanını hesaplarsam, dairenin alanını da hesaplamış olurum. İşte napıcaz? Matematikte, bu tarz yöntemlerle biz limitten faydalanıcaz. Veya devam edelim. Başka bi tane örnek verelim. Başka nasıl kullanırız?

Tahta:

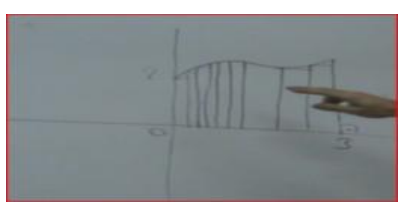

Can: Şu çizdiğim dörtgenleri birazcık daha küçültsem. Yani şöyle bi dörtgen çizsem. Sonra şöyle bi tane daha dörtgen çizsem. Bunu çizsem. Şuraları hep bölsem. Nolur? Dışarıda daha az alan mı kalır?

Öğrenci: İhmal edeceğimiz kadar kalır.

Can: Doğru. Gitgide şu dışarıda kalan alan, hesaplayamadığım alan daha az olur. Peki, ben sonsuz tane dikdörtgen çizersem, o zaman nolur? Ben bu eğrinin tamamını kaplamış olurum. Yani ben $n$ sonsuza giderken, dikdörtgen sayısı sonsuza giderken, bu alanı hesaplayabilirim.

Diğer disiplinler ile ilişkilendirmeden yararlanan tek katılımcı olan Umay üçüncü dersinde genişletilmiş gerçek sayılarda limit için sonsuzluk düşüncesini öğrencilerinde oluşturmaya çalışırken fizik derslerinde görülen paralel aynalarda görüntü oluşumunu ele almıştır.

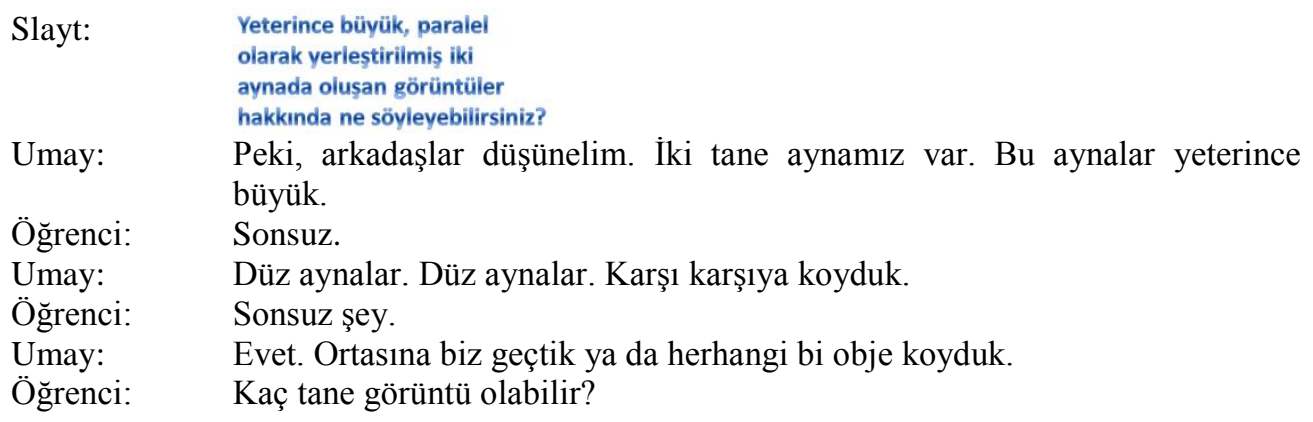




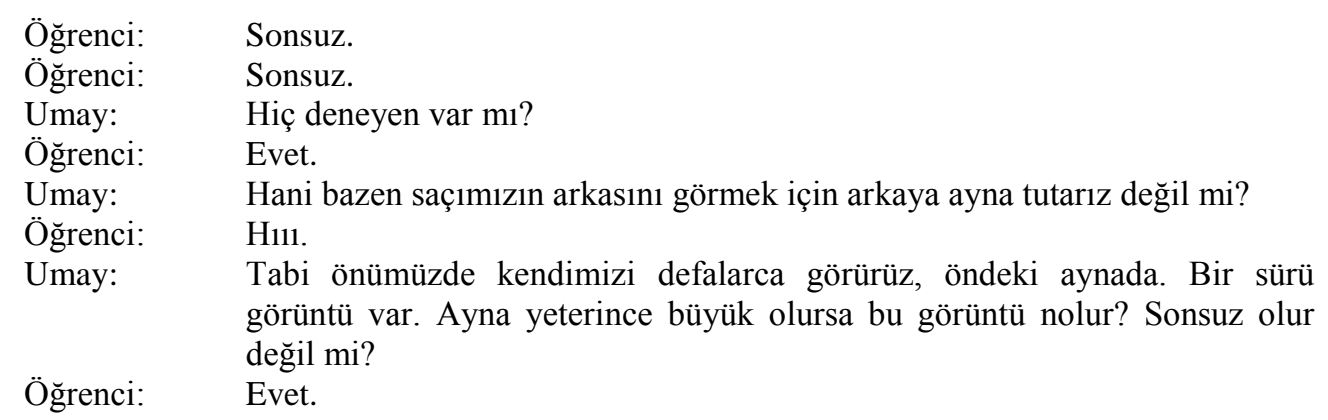

\section{Matematiksel Düşünme ve Akıl Yürütmeyi Sağlama}

Katılımcılardan Deniz, Umay ve Alev derslerinde öğrencilerinin matematiksel düşünme ve akıl yürütmelerini sağlamak için genellikle grup çalışmaları ve sınıf içi tartışmalar yaptırmışlardır. $\mathrm{Bu}$ süreçte özellikle Deniz ve Umay öğrencilerini, birbirlerinin düşüncelerini tartışmaya yönlendirmişler, onları dinlemişler ve düşüncelerine önem vererek sınıf arkadaşları ile paylaşmalarını sağlamışlardır. Böylelikle öğrencilerinin ne düşündüğünü ve nasıl bir akıl yürütme sonucunda bir takım sonuçlara ulaştıklarını görme şansı edinmişlerdir. Bununla birlikte katılımcılar, öğrencilerini düşünmeye yöneltme, yanıtlarını genişletme ve yanlışlarını buldurma amaçlı olarak sorular sormaya çalışmışlardır. Umay dördüncü dersinde öğrencilerini düşündürmek için trigonometrik fonksiyonların limitlerini bulmada radyan kullanımının tercih edilme nedenini sormuş ve onların yanıtlarını aşağıdaki gibi değerlendirmiştir.

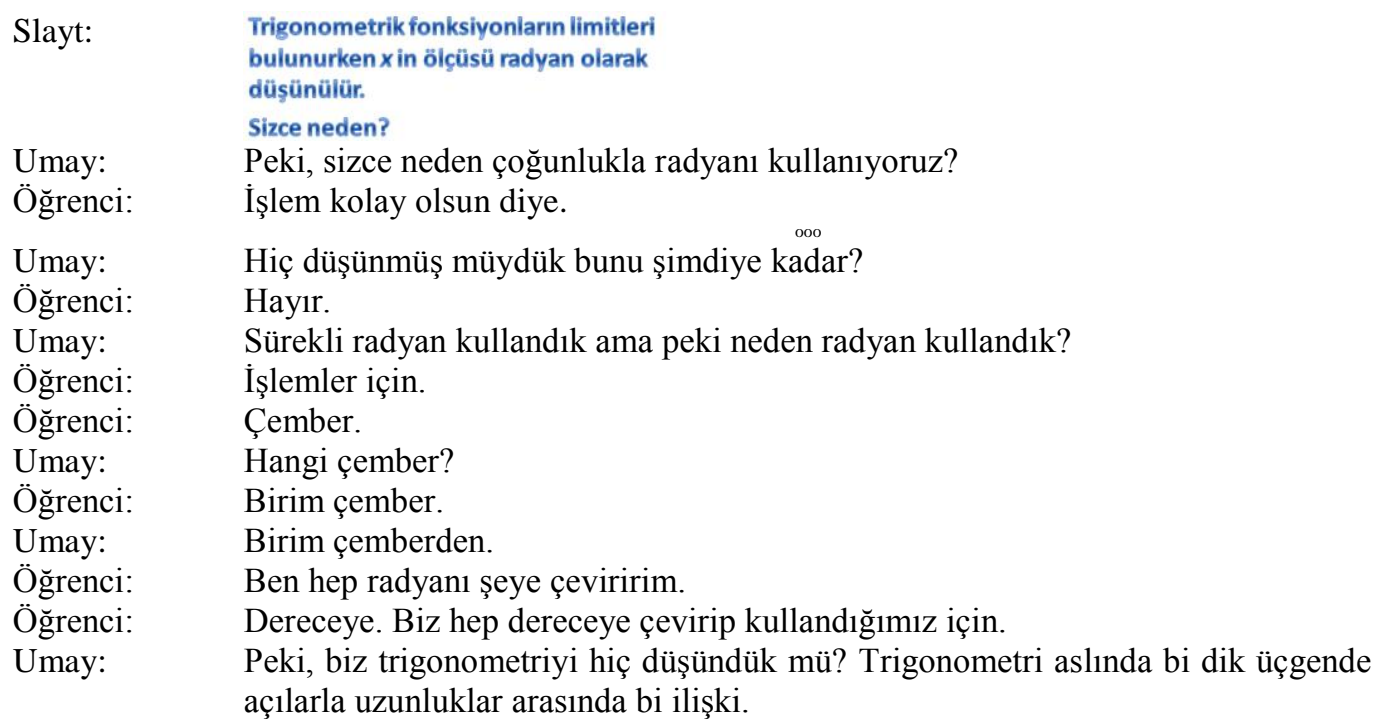

Deniz ve Umay genellikle öğrencilerine sordukları sorulara verdikleri yanıtlara nasıl ulaştıklarını anlatmalarını istemişler ve öğrencilerinin ihtiyaç duyduğunu ve teşvik edilmesi gerektiğini anladıklarında onları soruları ile yönlendirmeye çalışmışlardır. Böylelikle öğrencilerinin nasıl akıl yürüttüklerini ve nasıl düşündüklerini de anlamaya çalışmışlardır. Can ve Alev ise öğrencilerinin yanıtlarını genel olarak sorgulamamışlar, yanıta nasıl ulaştıkları ile ilgilenmemişler ve öğrencileri yanlış yanıtlar verdiklerinde onların bu yanlışlıklarını fark etmelerini sağlamak yerine doğrudan kendileri düzeltme yoluna gitmişler ve bazen de doğru yanıtı kendileri vermişlerdir. Bu nedenle de 
öğrencilerin neden hata yaptıklarını ve neyi yanlış düşündüklerini öğrenme şansı bulamamışlardır. Can bu bağlamda en sıkıntı yaşayan katılımcı olmuş ve öğrencilerine soru sorup onların yanıtlarını değerlendirmek ve düşüncelerini ortaya çıkarmak yerine kendi sorduğu sorulara yine kendisi yanıt vermeyi ve açıklamalarda bulunmayı tercih etmiştir. Can kendisi ile yapılan görüşmede sorduğu soruları çoğunlukla kendisinin yanıtlamayı tercih etme sebebini, öğrencilerin konuyu kavrayıp kavramadıklarını anlamak için uygulama soruları çözdürdüğünü ve özel olarak onlara sorular yöneltmeyi tercih etmediğini aşağıdaki gibi ifade etmiştir.

Öğrencilere özel olarak sorular yöneltmedim. Sadece konuyu kavrayıp kavramadıklarına bakabilmek için veya konuyu anladıktan sonra uygulama olsun diye öğrencilerle seçtiğim örneklerin çözümünü yaptık. (Can-Göstergelere İlişkin Görüşme)

\section{İletişim Kurma Becerisini Geliştirme}

Deniz, Umay ve Alev derslerinde gerekli gördükçe öğrencilerini birlikte çalıştırarak onların grup içinde birbirlerini dinleyip, düşündüklerini ifade etmelerini, düşüncelerinin altında yatan nedenleri belirtmelerini ve düşüncelerinin doğruluğunu/yanlışlığını tartışmalarını sağlamışlardır. Ek olarak öğrencilerine sorular sorup onların yanıtlamalarını istemişler ve sınıf içi tartışma ortamı yaratmışlardır. Alev limite ilişkin özelikleri öğrencilerine verdiği iki fonksiyon ile işlem yaptırarak kendilerinin çıkarmaları için grup çalışması yaptırmıştır. Bu süreçte özellikle Deniz ve Umay öğrencilerini düşüncelerine önem vermişler, onları dinlemişler, birbirlerinin düşüncelerini tartışmaya yönlendirmişler ve sınıf içi sağlıklı iletişim kurmayı sağlamışlardır. Deniz ilk dersinde sınıfı iki gruba ayırarak, bir sayıya sağdan ve soldan yaklaşımı öğrencilerine kavratmak amaciyla kurguladığı bir oyunu öğrencilerine oynatmıştır. Söz konusu oyunun kuralına göre; bir grup 5 sayısına dörtten diğer grup ise altıdan başlayarak yaklaşmaya çalışacak ve 5'e en fazla yaklaşabilen grup ise oyunun galibi olacaktır. Deniz oynattığı oyundaki gibi grup çalışmasından yararlanarak, öğrencilerinin hem gruplar içinde hem de sınıf arkadaşları ile iletişim kurmalarını sağlamıştır.

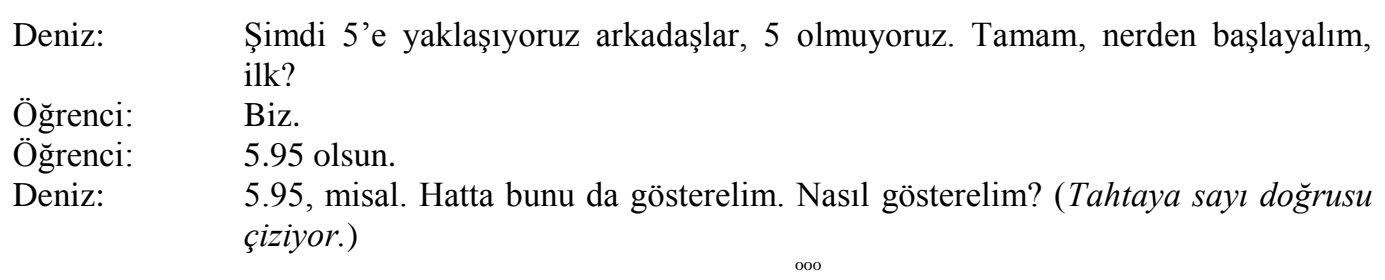

Slayt:

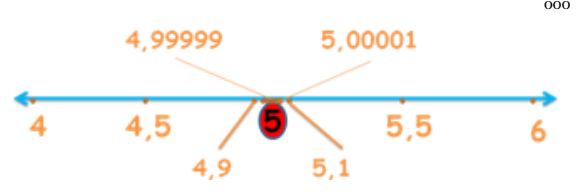

\section{Matematik Dilini Kullanma}

Katılımcılar öğretimlerinde genellikle matematik dilini doğru bir şekilde kullanmaya çalışmışlar ve öğrencilerinin de matematik dilini doğru bir şekilde kullanmalarına özen göstermişlerdir. Can matematik dilini doğru kullanmaya en çok 
dikkat eden katılımcı olmuş ve öğrencilerini de matematik dilini kullanırken dikkatli olmaya yönlendirmiştir.

Can: $\quad$ Bi de 3'e artıdan-eksiden yaklaşmıyo. Sağdan ve soldan yaklaşıyo. Anlaştık. Var $\mathrm{m} 1$ arkadaşlar problem? Yok mu? (Notlarına baktıktan sonra) Peki devam edelim. $f(x)$ eşittir mutlak değer $x-2$ olsun.

Bununla birlikte, Can tahtaya kalkan öğrencilerinin soru çözümleri süresince matematik dilini doğru kullanmalarına dikkat etmiş ve yanlış yazımlarını düzeltmeleri için onlara uyarılarda bulunmuştur. Can'ın üçüncü dersinde öğrencisi cebirsel ifadeyi yazarken bazı hatalar yapmış, Can söz konusu hataya dikkat çekerek öğrencilerinin bu hatanın farkına varmalarını sağlamıştır.

Tahta:

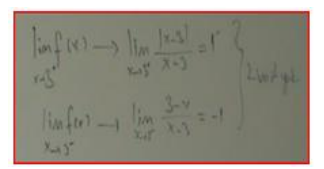

$$
\left.\begin{array}{l}
\lim _{x \rightarrow 3^{+}} f(x) \rightarrow \lim _{x \rightarrow 3^{+}} \frac{|x-3|}{x-3}=1 \\
\lim _{x \rightarrow 3^{-}} f(x) \rightarrow \lim _{x \rightarrow 3^{-}} \frac{3-x}{x-3}=-1
\end{array}\right\} \text { limit yok }
$$

Can: $\quad$ Teşekkür ederiz. Yalnız bak öyle ufak ufak çok değişik hatalar yapıyosunuz.

Öğrenci: $\quad$ Eşit.

Can: $\quad$ Eşittir demi, yaklaşmaz.

Tahta:

$$
\left.\begin{array}{l}
\lim _{x \rightarrow 3^{+}} f(x)=\lim _{x \rightarrow 3^{+}} \frac{|x-3|}{x-3}=1 \\
\lim _{x \rightarrow 3^{-}} f(x)=\lim _{x \rightarrow 3^{-}} \frac{3-x}{x-3}=-1
\end{array}\right\} \text { limit yok }
$$

Katılımcıların matematik dilini doğru kullanamadıkları ve öğrencilerinin kullanımlarına dikkat etmedikleri durumlar da gözlenmiştir. Deniz’in öğrencileri limiti olmayan bir fonksiyon örneği için "limit değil” ifadesini kullanmıştır. Deniz bu ifadeyi düzeltmek yerine kendisi de "ama limit değiller" diyerek dersine devam etmiştir. Benzer şekilde, bir öğrenci 2'ye soldan ve sağdan yaklaşım yerine "2'nin eksi ya da artısı" ifadesini ya da "kısmen limit" ifadesini kullandığında Deniz öğrencisinin yanlışını düzeltmek yerine aynı ifadeleri kullanmıştır. Benzer sıkıntılar Umay'ın dördüncü dersinde de görülmüş̧ür.
Öğrenci:
H1 hı evet. Eksi yönde artıyo yani.
Umay:
Evet, eksi yönde artıyo diyebiliriz. $f(x)$ 'im noluyodu? Sürekli artıyodu. Grafiği hatırlıyoruz demi. Kolları yukarı doğru. Yine $g(x)$ 'im $2 x$ kareydi, $x$ 'lerim eksi sonsuza doğru giderken $111 g(x)$ 'im de sonsuza gidiyodu. Sonsuz kavramını yeterince konuştuk.
Şimdi diğer taraftan 0'a yaklaşalım. Ki bunu grafik üzerinde görmüştük. Şimdi
Umay: tablo üzerinde bi daha görüyoruz. 0'a giderek yaklaşıyorum. Değerlerimiz negatif yönde giderek artıyo. O zaman $x$ 'lerim 0 'a soldan yaklaşırken $f(x)$ 'im de eksi sonsuza yaklaşır.

Umay kendisi ile yapılan görüşmede dersinde ifade ettiği eksi yönde artmanın ne anlama geldiğgine ilişkin soruya aşağıdaki gibi yanıt vermiştir.

Sanırım burda kullanma amacım benim öğrencilerden gelen 111 öğrencilerin söyledikleri şeye göre oldu biraz da. Hani böyle bi ifade aslında kullanmamıştım ama öğrencilerden hani bi tanesi "eksi yönde artıyo yani" deyince ben evet eksi yönde artıyo dedim. Onu da şöyle düşündüm. Iı1 eksi sonsuza doğru yaklaşıyo. Hani 111 işaretinden bağımsız olarak artıyo. Eksi 
sonsuza doğru giderek yaklaşıyo. Sanırım öğrenci o şekilde anlamıştı ve ben de hani onun anladığı şekilde ifade etmeye çalışırken böyle bi ben de bir kavram kargaşasına düştüm.(Umay, Dördüncü Ders Sonu Görüşme)

\section{Matematik ile Sanatı İlişkilendirme}

Katılımcılardan Deniz, Umay ve Alev limit kavramının öğretiminde matematiksanat ilişkilendirmesine özen göstermişlerdir. Deniz ilk dersine girişte limit kavramı ile ilgili olacağını düşündügü bir videoyu öğrencilerine sunmuş ve böylelikle öğrencilerinin dikkatini çekerek dersini eğlenceli bir hale getirmeye çalışmıştır (bkz. Şekil 2).

Şekil 2. Deniz'in video sunumundan kesitler

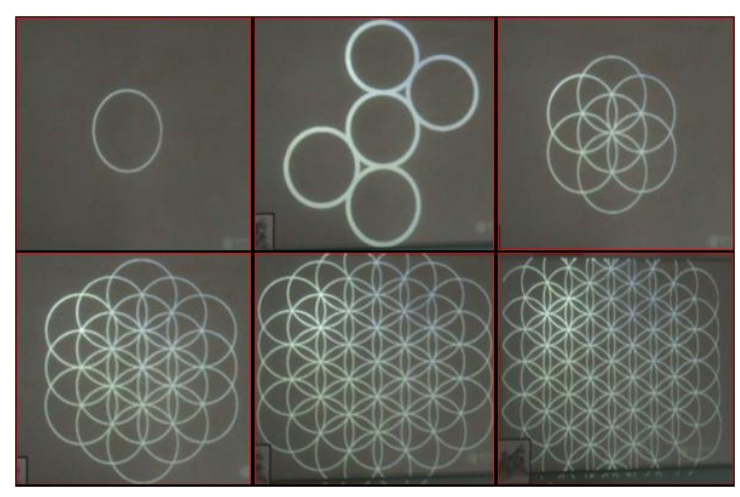

Umay ve Alev matematik-sanat arasında ilişki kurmak için Escher'in Şekil 1'deki resimlerinden yararlanmıştır. Bu resimler ile şekillerin bir daireye benziyor gibi gözükmesine rağmen daire olmadıklarını, motiflerin gittikçe küçüldüğünü ancak aynı motifin sürekli devam ettiğini ifade etmişlerdir (bkz. Şekil 3).

Şekil 3. Umay ve Alev'in limit kavramında kullandıkları Escher'in resimleri
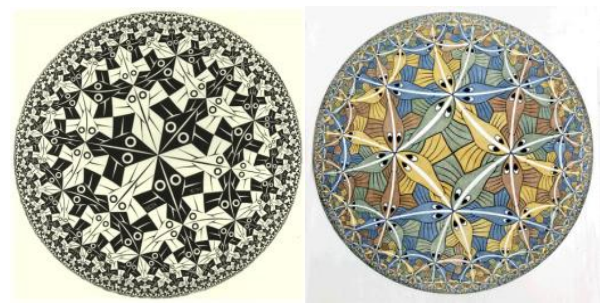

Umay üçüncü dersinde ise Escher'in Şekil 4'deki iki resminden yararlanarak öğrencilerine sonsuzluk kavramını sezdirmeye çalışmıştır.

Şekil 4. Umay'ın sonsuzluk kavramında kullandığı Escher'in resimleri

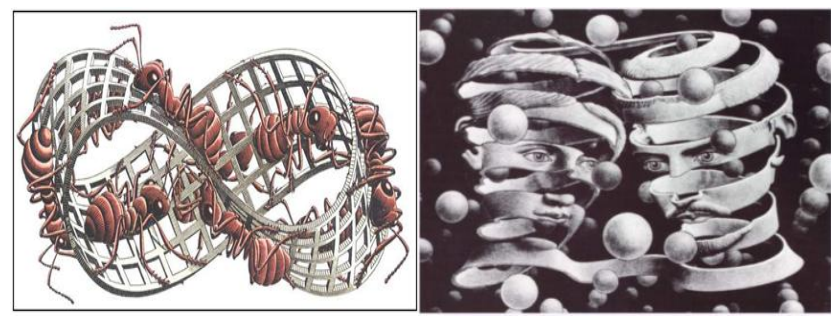




\section{Teknolojiyi Etkin Kullanma}

Deniz, Umay ve Alev limit öğretimlerinde teknoloji ve teknolojinin sunduğu imkanlardan, hazırladıkları Powerpoint sunularını projeksiyon aracılığı ile tahtaya yansıtarak yararlanmışlardır. Matematiğe özgü yazılımları ise sadece Umay ve Alev kullanmışlardır. Umay bazen animasyonlardan yararlanmış bazen ise limit değerini bulmada sağdan-soldan yaklaşımın önemini vurgulama ve genişletilmiş gerçek sayılar kümesinde fonksiyonun bir noktasındaki limitini bulma vb. durumlarda matematiksel bir yazılım olan DERIVE'daki grafik çizimlerinden yararlanmıştır. Böylelikle grafik üzerinde komşulukları gösterme şansını da elde etmiştir. Umay, kendisi ile yapılan görüşmede derslerinde söz konusu yazılımdan yararlanmayı tercih etme nedenini aşağıdaki gibi açıklamıştır.

I11 öncelikle hani kendim çizebilirdim grafikleri ama 111 tam net bi şekilde çizebileceğimi düşünmüyorum hani ufak kaymalar falan olurdu. I11 zaten hani öğretmenleri sürekli kendisi grafik çiziyo. Öncelikle hani dikkatini çekmek istedim öğrencilerin. Hani böyle bi program var ve bu programda bu tarz şeyler yapabiliyoruz. İkincisi hani somutlaştırmayı daha düzgün bi şekilde yapmak istedim. Hani neyin nerde işte noktaları tam olarak görsünler, ne nerde neyi kesiyo görsünler istedim. O yüzden kullandım. (Umay-Dördüncü Ders Sonu Görüşme)

Umay DERIVE programının dinamikliğinden faydalanarak fonksiyonun farklı $\mathrm{x}$ değerleri için limitinin ne olduğunu öğrencilerine dördüncü dersinde aşağıdaki kesitte verildiği gibi göstermiştir.

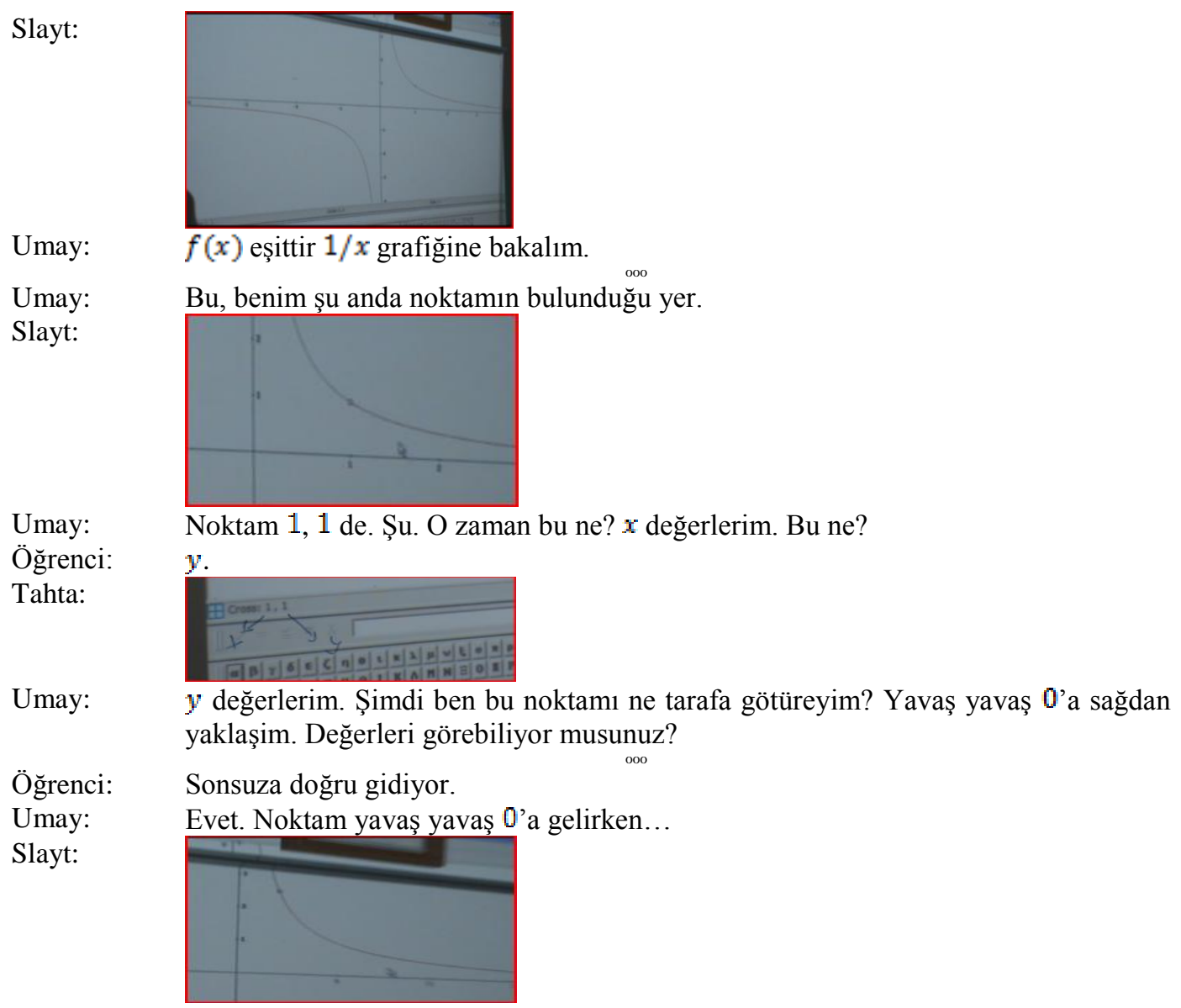


Alev de Umay gibi matematiğe özgü yazılımlardan derslerinde yararlanmayı tercih etmiştir. İlk dersinde MATLAB'ı kullanarak fonksiyonun verilen bir noktasındaki limitini bulmada sağdan ve soldan yaklaşımı vurgulamıştır. Alev, seçtiği fonksiyonun $x=10$ 'daki limitini araştırırken, önce tablo ile gösterim yapmış ardından ise yazılım yardımıyla fonksiyonun grafiğini çizip $x=10$ 'a sağdan ve soldan yaklaşma durumunda fonksiyonun yaklaştığı değerlerin ne olacağını tartışmıştır.

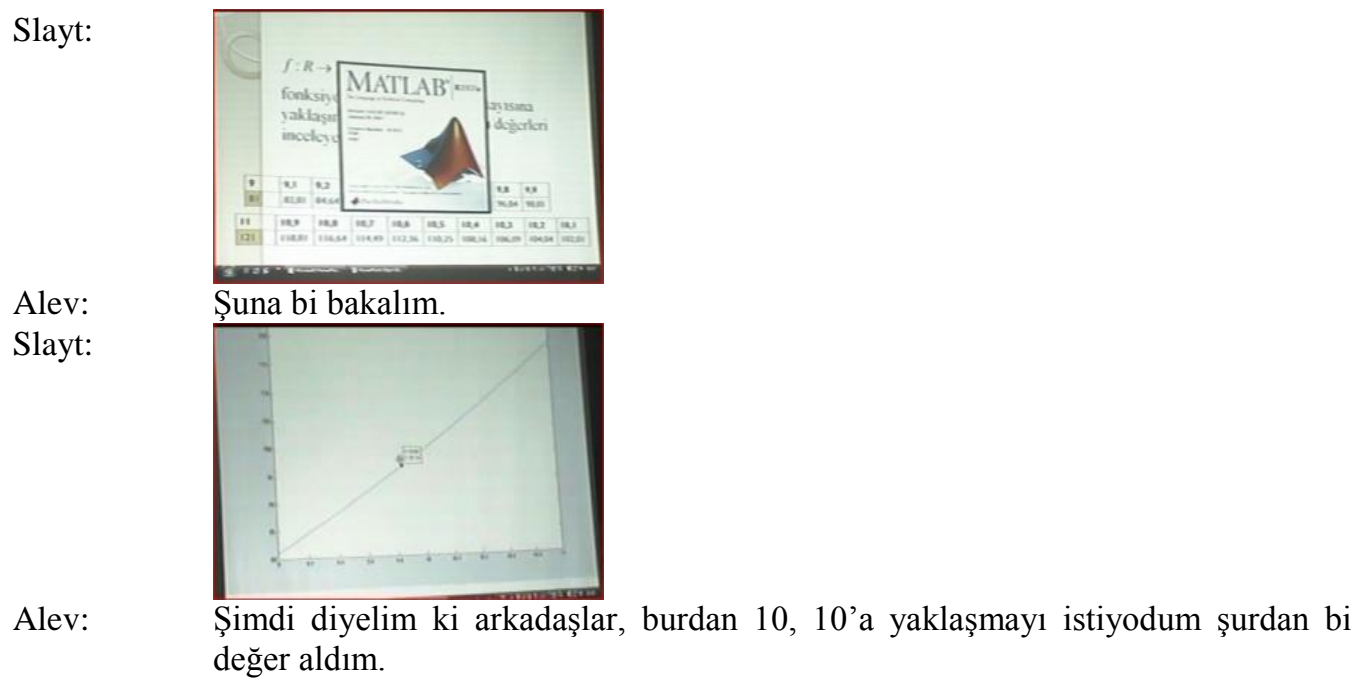

\section{Sonuç ve Tartışma}

Matematik öğretmen adaylarının öğretim programının amaçlarına yönelik bilgilerinin limit öğretimlerine yansımalarının; günlük yaşamla ilişkilendirme, farklı öğrenme alanlarıyla ilişkilendirme, matematiksel düşünme ve akıl yürütmeyi sağlama, iletişim kurma becerisini geliştirme, matematik dilini kullanma, matematik ile sanatı ilişkilendirme ve teknolojiyi etkin kullanma başlıkları altında şekillendiği görülmüştür. Katılımcıların limit öğretimine ilişkin dersleri incelendiğinde söz konusu amaçların genel olarak farkında oldukları ve derslerini bu amaçlar doğrultusunda planlayıp yürüttükleri görülmüştür.

Katılımcıların matematik öğretimine bakış açıları onların öğretimlerinde kullanacakları yaklaşımları belirlemede etkin rol oynamıştır. Yapılandırmacı yaklaşımı benimseyen öğretmen adayları, matematiğin neden öğrenildiğini, ne işe yarayacağını, günlük yaşam ve diğer bilimlerle nasıl ilişkili olduğunu öğrencilerine ifade etmeye çalışmışlardır. Bunun yanında geleneksel yaklaşımı benimseyen bir katılımcı ise kendisinin geleneksel yolla öğrendiği ve öğrenmenin ancak birey isterse gerçekleşebileceği savından hareketle öğretimini bu yönde şekillendirmiştir. Buradan hareketle öğretmen adaylarının OMDÖP'te yer alan matematik öğretiminin amaçlarına limit derslerinde yer vermeleri, kendilerinin benimsedikleri anlayış çerçevesinde şekillendiği söylenebilir.

Bir katılımcı derslerinde günlük yaşam örneklerinden yararlanmayı tercih etmezken, üç katılımcı günlük yaşamla ilişkilendirmeyi ağırlıklı olarak limit düşüncesinin oluşturulmaya başlandığ 1 ilk derslerinde kullanmayı tercih etmişlerdir. Bir katılımcı limit kelimesinin Türkçede ne anlama geldiğini öğrencilerine açıklarken, iki 
katılımcı limit kavramı için hız limiti, kredi kartı limiti gibi günlük yaşamda kullandığımız limit kelimesine ilişkin örnekleri vermişlerdir. Katılımcıların bu örnekleri öğrencilerinde limitin en alt ve en üst sınır olduğu düşüncesinin oluşmasına neden olmuş ve yansımaları öğrencilerin verdikleri günlük yaşam örneklerinde görülmüştür. $\mathrm{Bu}$ tarz örneklendirmelerin limitle ilgili ön kavrayışlara dayalı yanılgılar bağlamında; öğrencilerde kavram yanılgısı oluşumuna neden olabileceği düşünülmektedir. Söz konusu örnekler ile limit kavramı genellikle ulaşılabilecek en üst değer ve aşılmaması gereken bir sınır olarak algılanmakta (Cornu, 1991; Davis, \& Vinner, 1986; Szydlik, 2000; Tall, \& Schwarzenberger, 1978; Williams, 1989) ve bu yönüyle matematiksel limit ile ters düşmektedir (Özmantar, \& Yeşildere, 2008). Bu yanılgının giderilmesinde; limitin günlük dildeki kullanımı ile matematikteki anlamı arasındaki farka değinme veya limitin aşılmaması gereken bir sınır olarak görülmesini engelleyecek örnekler verme uygun olacaktır. Bir katılımcı verdiği ünlüye yaklaşım örneğinde ünlüye hiçbir zaman ulaşılamayacağına dair vurgu yapmıştır. Bu şekilde bir vurgunun limit değerine asla ulaşılamayacağına dair bir kavram yanılgısına (Szydlik, 2000; Williams, 1989, 2001) sebep olabileceği düşünülmektedir. Elia ve ark. (2009) bu konuya dikkat çekerek, öğrencilerin sahip olabilecekleri olası kavram yanılgılarından haberdar olunması ve öğretimin de bu doğrultuda şekillendirilmesi gerektiğini belirtmektedirler. Katılımcıların söz konusu günlük yaşam örneklerini derslerine taşımalarının önemli olduğu düşünülmekle beraber, bu tarz örneklerin kavram yanılgılarına neden olabileceği göz önüne alınarak çok iyi tasarlanması önerilmektedir. Günlük yaşam örneklerinin öğrenciler için dikkat çekici olduğu göz önüne alındığında, bu örnekler kullanılırken gerekli açıklamaların yapılması ve böylece kavram yanılgıları oluşumunun önüne geçilmesi gerekmektedir.

Katılımcıların limit kavramını genellikle geometrik kavramlar ile ilişkilendirmeyi tercih ettikleri, bir katılımcının ise fiziksel kavramlar ile ilişkilendirecek örnekleri de öğrencilerine sunduğu görülmüştür. Yapılandırmacı anlayışı benimseyen üç katılımcı öğrencilerin matematiksel düşünme ve akıl yürütmelerini sağlamak amacıyla onlara sorular yöneltmiş, onların düşüncelerini dinlemiş ve böylelikle düşünme yollarını anlamaya çalışmıştır. Söz konusu üç katılımcı, grup çalışmalarından yararlanarak öğrencilerinin düşüncelerini grup ve sınıf arkadaşları ile paylaşmalarını sağlamışlardır. Böylelikle öğrencilerinin iletişim kurma becerilerini geliştirmeye çalıştıkları düşünülmektedir. Geleneksel anlayışa sahip olan katılımcı ise genellikle öğrencilerine sorduğu sorulara onların düşünmelerine fırsat vermeden kendisi yanıt vermiştir. Özellikle söz konusu katılımcının kavrama ulaşma aşamasında öğrencilerine sorular sormadığ 1 , var olan düşüncelerini ortaya çıkarmaya çalışmadığı, sorgulama yaptırmadığı ve genellikle kavramın uygulaması için öğrencilerine işlem yapmaya yönelik sorular sorduğu görülmüştür. Yapılandırmacı anlayışa sahip bir katılımcı ise öğrencileri yanlış yanıtlar verdiklerinde yanlışın nedenini ve öğrencilerinin akıl yürütmelerini belirlemediği için doğrudan kendisi düzeltmeler yaparak doğru yanıtı vermeye çalışmıştır. Katılımcının benimsediği anlayış gereği sadece öğrencinin kavrama ulaşması aşamasında değil her aşamadaki düşüncelerini dikkate alması gerekirdi. 
Katılımcılar genel olarak matematik dilini doğru kullanmaya ve öğrencilerinin de doğru kullanmalarına özen göstermişlerdir. Özellikle bir katılımcı bu konuda oldukça titiz davranmış ve öğrencilerinin matematik dili kullanımlarını dikkatle izleyerek yanlış kullanımlarını düzeltme yoluna gitmiştir. Bunun yanında katılımcıların matematik dilini yanlış kullandıkları durumlar da ortaya çıkmıştır. Benzer şekilde Moore (1994) da matematik veya matematik eğitimi okuyan üniversite öğrencileri ile yaptığı çalışmasında, onların matematik dili kullanımında sıkıntı yaşadıklarını belirtmektedir (akt. Sarı, Altun, \& Aşkar, 2007). Matematik dili kullanımındaki söz konusu sıkıntıların öğrencilerde de yansımaları olabileceği göz önüne alındığında, öğretmen adaylarının doğru bir matematik dili kullanımına sahip olmalarının önemli olduğu düşünülmektedir. Böylelikle öğrencilerin de doğru bir matematik dili kullanımına sahip olmaları sağlanmış olacak ve sonraki konular için bir zemin oluşturarak öğrencilerin matematiksel gelişimleri olumlu yönde etkilenebilecektir (Doğan, \& Güner, 2012). Bunun yanında öğretmen adaylarının yeni bir matematiksel ifadeyi öğrencilerine tanıtma sürecini iyi planlamaları gerektiği belirtilmektedir (DfEE, 1999). Öğretmen adayları öğretim sürecinde öğrencilerin matematiksel kavramlarla ilgili konuşmalarını, tahtada problem çözüp, bu çözümü ifade etmelerini vb. sağlayacak (Aydın, \& Yeşilyurt, 2007) ortamları tasarlanmalarının önemli olduğuna ilişkin bilgilendirilmelidirler. Öğretmen eğitiminde, öğretmen ve öğrenciler tarafından matematik dili kullanımının önemine ilişkin farkındalık sağlanmalıdır.

İki katılımcı matematik ile sanatı ilişkilendirmek amacıyla limit öğretimlerinde Escher'in resimlerinden yararlanmışlardır. Bir katılımcı ise limit kavramına girişte, geometrik şekillerin estetik olarak birleştirilmesiyle oluşturulan bir videodan yararlanarak öğrencilerinin dikkatini konuya çekmeye çalışmıştır. Üç katılımcı hazırladıkları Powerpoint sunumları ile derslerini yürütürken, iki katılımcı teknolojiden matematiksel yazılımları kullanarak da yararlanmışlardır. Analiz öğretiminde Graphical Calculus gibi matematiksel yazılımların kullanılması; cebirsel, grafiksel ve tablo ile gösterimleri sunabilmek amaciyla önerilmektedir (Akkoç, 2006). Bu bağlamda katılımcıların limit öğretimlerinde matematiksel yazılımlardan yararlanmalarının önemli olduğu düşünülmektedir. 


\section{Kaynakça}

Akkoç, H. (2006). Bilgisayar destekli matematik öğretimi: grafik analiz yaklaşımı: ilköğretim ikinci kademe ve liseler için. İstanbul: Toroslu Kitaplı̆̆ı.

An, S., Kulm, G., \& Wu, Z. (2004). The pedagogical content knowledge of middle school mathematics teachers in China and the U.S. Journal of Mathematics Teacher Education, 7, 145-172.

Aydın, S., \& Yeşilyurt, M. (2007). Matematik öğretiminde kullanılan dile ilişkin öğrenci görüşleri. Elektronik Sosyal Bilimler Dergisi, 6(22), 90-100.

Ball, D. L., \& McDiarmid, G. W. (1990). The subject matter preparation of teachers. In R. Houston (Eds.), Handbook of research on teacher education. New York: Macmillan.

Bukova Güzel, E. (2010). An investigation of pre-service mathematics teachers' pedagogical content knowledge, using solid objects. Scientific Research and Essays. 5(14), 1872-1880.

Bukova, E. (2006). Öğrencilerin limit kavramını algılamasında ve diğer kavramların ilişskilendirilmesinde karşılaştıkları güçlükleri ortadan kaldıracak yeni bir program geliştirme (Yayımlanmamış doktora tezi). Dokuz Eylül Üniversitesi Eğitim Bilimleri Enstitüsü, İzmir.

Chıck, H., Baker, M., Pham, T., \& Cheng, H. (2006). Aspects of teachers' pedagogical content knowledge for decimals. In J. Novotna, H. Moraova, M. Kratka \& N. Stehlikova (Eds.), Proceedings of the 30th Conference of the International Group for the Psychology of Mathematics Education (Vol. 2, pp. 297-304). Prague: PME.

DfEE (1999). Mathematical Vocabulary. London: DfEE.

Doğan, M., \& Güner, P. (2012). Illköğretim matematik öğretmen adaylarının matematik dilini anlama ve kullanma becerilerinin incelenmesi. X.Ulusal Fen Bilimleri ve Matematik Eğitimi Kongresi, Niğde, Türkiye.

Elia, I., Gagatsis, A., Panaoura, A., Zachariades, T., \& Zoulinaki, F. (2009). Geometric and algebraic approaches in the concept of "limit" and the impact of the "didactic contract”. International Journal of Science and Mathematics Education. 7, 765790 .

Grossman, P. (1990). The making of a teacher: Teacher knowledge and teacher education. New York: Teachers College Press.

Hill, H., Ball, D. L., \& Schilling, S. (2008). Unpacking 'pedagogical content knowledge': Conceptualizing and measuring teachers' topic-specific knowledge of students. Journal for Research in Mathematics Education. 39, 372-400.

Hofe, R. V. (1997). Problems with the Limit Concept on A Case Study of A Calculus Lesson Within Computer-Based Learning Environment. <http://www.fmd.uniosnabrueck.de/ebooks/gdm/PapersPdf1997/vomHofe.pdf.> (15.06.2003). 
Leavit, T. A. (2008). German mathematics teachers' subject content and pedagogical content knowledge (Unpublished doctoral dissertation). University of Nevada, Las Vegas.

Magnusson, S., Borko, H., \& Krajcik, J. (1999). Nature, sources, and development of pedagogical content knowledge for science teaching. In Gess-Newsome, J., \& Lederman, N.G. (Eds.), Examining Pedagogical Content Knowledge (95-132). Dordrecht: Kluwer Academic Publishers.

Marks, R. (1990). Pedagogical content knowledge: from a mathematical case to a modified conception. Journal of Teacher Education. 41(3), 3-11.

MEB, (2006). Ortaöğretim matematik dersi öğretim programı. Ankara: MEB Basımevi.

Orton, A., (1983). Students understanding of integration. Educational Studies in Mathematics. 14, 1-18.

Özmantar, M.F, \& Yeşildere, S. (2008). Limit ve süreklilik konularında kavram yanılgıları ve çözüm arayışları. Özmantar, M. F., Bingölbali, E. ve Akkoç, H. (Ed), Matematiksel Kavram Yanılgıları ve Çözüm Önerileri (181-221). Ankara: Pegem Kitabevi.

Rowland, T., Turner, F., Thwaites, A., \& Huckstep, P. (2009). Developing primary mathematics teaching: reflecting on practice with the knowledge quartet. London: Sage.

Sanchez, R. A. (1996). Teacher's and students' mathematical thinking in a calculus classroom: the concept of limit, UMI Microform 9700247, (Doctoral dissertation). Florida State University, College of Education, USA.

Sarı, M., Altun, A., \& Aşkar, P. (2007). Üniversite öğrencilerinin analiz dersi kapsamında matematiksel kanıtlama süreçleri: Örnek olay çalışması. Ankara Üniversitesi Eğitim Bilimleri Fakültesi Dergisi, 40(2), 295-319.

Schoenfeld, A. H. (1998). Toward a theory of teaching-in-context. Issues in Education. $4(1), 1-94$.

Shulman, L. (1986). Those who understand knowledge growth in teaching. Educational Researcher. 15(2), 4-14.

Shulman, L. (1987). Knowledge and teaching: Foundations of the new reform. Harvard Educational Review. 57(1), 1-22.

Szydlik, J. E. (2000). Mathematical beliefs and conceptual understanding of the limit of a function. Journal for Research in Mathematics Education, 31(3), 258-276.

Tamir, P. (1988). Subject matter and related pedagogical knowledge in teacher education. Teaching and Teacher Education, 4(2), 99-110.

Williams, S. R. (1989). Understanding of the limit concept in college calculus students (Doctoral dissertation). The University of Wisconsin, Madison.

Williams, S. R. (2001). Predications of the limit concept: An Application of repertory grids. Journal for Research in Mathematics Education. 32(4), 343-367. 